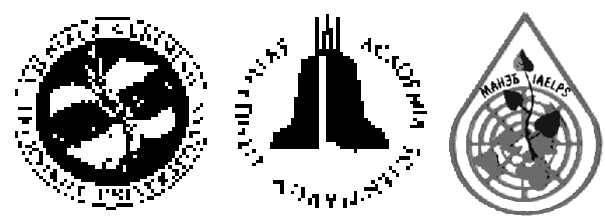

\title{
INVESTIGATION AND EVALUATION OF SOIL POLLUTION WITH OIL PRODUCTS IN THE MOST INTENSIVELY USED TERRITORIES OF GAIŽIŪNAI MILITARY TRAINING GROUND
}

\author{
Saulius Vasarevičius, Kristina Greičiūtė, Edita Šiaulytė \\ Dept of Environmental Protection, Vilnius Gediminas Technical University, \\ Saulètekio al. 11, LT-10223 Vilnius-40, Lithuania \\ E-mail:krist@ap.vtu.lt
}

Received 29 Aug 2005; accepted 28 Sept 2005

\begin{abstract}
Recently environmental pollution became a problem of a special significance. Removal of pollutants from territories suffering from intensive use in the past and at present attracts major concern. Extensive pollution of the soil with materials of organic origin (oil and its products) was detected in the areas of the former military bases of different operation types. The surface soil is the first natural system to be directly affected by any level of pollution and it accumulates pollutants. Water dissolves and washes out materials from the soil saturated with oil hydrocarbons and it is also polluted with oil products.

The present paper describes the evaluation of environmental pollution caused by military activity in the operating Rukla-Gaižiūnai Military Training Ground. After investigation of soil pollution with oil products was performed, it was possible to analyse particularly the present soil condition and assess the most contravened places referring to the obtained results.
\end{abstract}

Keywords: military training grounds, soil pollution, oil products, mathematical modeling.

\section{Introduction}

Pollution of the Lithuanian soil with oil products is not very extensive in comparison with pollution levels in major West European and American countries. However, a distinctive feature of our country is the heritage of the soviet army. Extensive pollution was detected in the areas of the former military bases of different functional types. Upon the retreat of the USSR army Lithuania retained 277 military territories of 67762 ha in total area $[1,2]$. The soldiery used their territories neglecting elementary environmental requirements. The total number of registered environmental violations in these territories is 2743 .

Military training grounds occupy large areas and they are usually established in distant forested locations, very often featuring beautiful landscape, almost extinct biocenosis of a high environmental value. Active operation of military training grounds pollute and destroy their environment and that of neighboring regions, without excluding cases when it has a hazardous effect on human health [3, 4].

Suggestion to close military training grounds would sound unrealistic and unwise in the today's context. The present paper seeks to evaluate environmental pollution caused by military activity in the operating Gaižiūnai Military Training Ground under study in order to find ways of optimizing the military activity of the soldiery so that a negative effect on the environment gets minimal and the damage done could be remedied.

Gaižiūnai Military Training Ground is of the most widespread military territory type. The Military Training Ground, the soil pollution of which was investigated, is located near Gaižiūnai village. Pine woods surround the village from the east, south and west, the soil is sandy, but lower lands are marshy. The proximity of the administration boundary and the protests of the Polish people prevented the Lithuanian army from the operation of the old Varna Military Training Ground (ref. Alytus county of the Lithuanian land). Therefore, the army bought a land plot from its owners in Gaižiūnai $6-9 \mathrm{~km}$ in width and up to $16 \mathrm{~km}$ in length, in total a $80 \mathrm{~km}^{2}$ area, and in 1931 established several military training camps - a military training ground usually called Gaižiūnai Military Training Ground. 
Later the Military Training Ground expanded to a number of buildings, military quarters, vast training firing grounds, airport, and railway branch-line. Every year, especially in the period of May - September, Gaižiūnai hosts numerous army troops, national service soldiers and reserve soldiers for training purposes [4]. The number of soldiers in the Military Training Ground is not constant. The traffic of the machinery and troops is very intensive because of regular training within the territory of the Military Training Ground. Territories of such a type as Gaižiūnai Military Training Ground used to be component parts of entire complexes of military training grounds, tank motordromes and firing grounds. Such territories feature vast areas, forestry environment, rather secluded location and long distance from civil settlement. Intensive military training activity in such territories resulted in an extensive damage to landscape, soil and often a harmful effect on plants [5]. In addition, many military training ground territories hosted military 'towns' of various assignment with living houses and maintenance buildings, including car service stations. Vast areas are littered with a variety of waste and even explosives. The surface soil is the first natural system to be directly affected by any level of pollution and it accumulates pollutants [6-8]. Water dissolves and washes out materials from the soil saturated with oil hydrocarbons and heavy metals, and it is also polluted with oil products and heavy metals. Such a soil needs treatment because pollutants accumulated in it may volatilize into the environment or, even worse, migrate downwards to the depth polluting groundwaters $[9,10]$.

The biggest source of pollution with oil products in operated and non-operated military training grounds are, of course, activities, related with the use of military transport. Territories used for military transport means are not only fields for military transport trainings and testing, not only aerodromes, tankodromes and autodromes, but also territories with specific buildings and equipment, like gasstations, underground gas storages, filing stations, etc. Big danger of oil product (fuel, fats) leaks occurs when filling storages or tanks with gas or fuel, and exploiting military transport means. Three types of territories can be outlined according to specific features of their pollution with oil products: 1) territories used directly for transport needs (aerodromes, tankodromes, autodromes, roads, etc); 2) territories used for tactical training using military transport; 3) military bases with gas-stations and fuel tanks. It is necessary to note that pollution with oil products can be induced not only by military transport, but also by other activities. For example, fats used to clean the ammunition can easily get into the environment and pollute the soil [11, 12].

The objectives of the work were to explore the results of investigation of soil pollution with oil products performed in Gaižiūnai Military Training Ground; to analyse the present soil condition and define the worst damage points based on the results of the investigation; to simulate a probable scope of further dispersion of pollution in the main pollution trouble-spots of the soil.

\section{Investigation methodology}

Soil sampling for geochemical analysis was performed in Gaižiūnai Military Training Ground on 10-12 September 2002. The air temperature during sampling ranged from $+12{ }^{\circ} \mathrm{C}$ - at 9.00 a. m. up to $+25{ }^{\circ} \mathrm{C}$ at $2.00 \mathrm{p}$. m. The humidity of the surface soil layer (under analysis) ranged from 40 to $45 \%$, while the relative humidity of the air was $50 \%$.

The criteria for selection of soil sampling places were the intensity of territory use (selecting places of the most intensive military activities) and consideration of pollution probability in certain places where the activities were performed in soviet times. In order to evaluate dependence of pollution dispersion on depth additional soil samples were taken in 4 places (at 2 points in the airport and at 2 points in an abandoned military settlement) at $1 \mathrm{~m}$ depth. Additional soil samples were taken for determination of the background concentrations of oil products. The points selected for such sampling were in higher places distant from the possible source of pollution at least visually considered as not affected by military activities.

Two sites were chosen for investigation. The first one - a landing airport established in the southern part of Gaižiūnai - Rukla massif (Fig 1). A vast wasteland surrounds the airport formed in an artificial way due to intensive military activities (explosions, testing of military machinery, trainings, etc). The airport has two concrete-covered landing-take-off runways directed towards northwest and southeast; the length of one runway is about $2100 \mathrm{~km}$, another one is a bit shorter. There are parking sites near the airport and a site for helicopter landing. The airport was not used intensively, and there were no oil storages, aircraft service installations, etc. However, take-off and landing as well as maneuvering of aircrafts always retain probability of oil or fuel leakage resulting in soil pollution. To prove such a probability soil samples for analysis of pollution with heavy metals and oil products were taken at the points alongside the take-off and landing runways to obtain the profile of pollutant distribution. Sampling points were selected as follows: a network was set alongside the runways at intervals of $400 \mathrm{~m}$, and samples were taken on both sides of the take-off and landing runways (of the two samples one was taken at $10 \mathrm{~m}$ distance from the runway, another one - at $100 \mathrm{~m}$ distance). In this way it was possible to obtain 7 transverse and 4 longitudinal samples. In general, 28 samples were taken. In a green zone between the take-off and landing runways soil samples were taken at two points from a deeper layer of up to $1 \mathrm{~m}$ depth (Fig 1).

The second site for soil sampling was chosen in the territory of an abandoned military settlement in the southern part of Gaižiūnai Military Training Ground, not far from the aerodrome. In the past such a type of settlements used to have not only communal buildings but also garages, different types of storage facilities, repair shops, etc. The abandoned military settlement in Gaižiūnai Military Training Ground was started by the Lithuanian army before the 
First World War; later it became a settlement of the soviet army. During the whole period, when the soviet army stayed there, the area was intensively used what could result in a negative impact on the environment. At present the area is not used any more, it contains only the remains of the former military settlement.

For the above mentioned reasons it is likely that pollution with oil products will be quite high.

Soil samples from the abandoned military settlement were taken trying to cover the whole territory (Fig 2). In general, 16 samples were taken, soil samples were also taken at two points from a deeper soil layer at up to $1 \mathrm{~m}$ depth.

Accumulation of pollutants in the soil is a long-term process; therefore, the investigation data given in the present paper indicate the existing pollution level but not changes in pollutant amounts.

Maximum allowed levels of pollution with oil products of the upper level of the lithosphere are defined by the standard HN 60:2004. Pollution of the lithosphere with oil products is indicated by a general amount of aliphatic, alicyclic and aromatic hydrocarbons in the soil exceeding a natural concentration formed in the environment. The

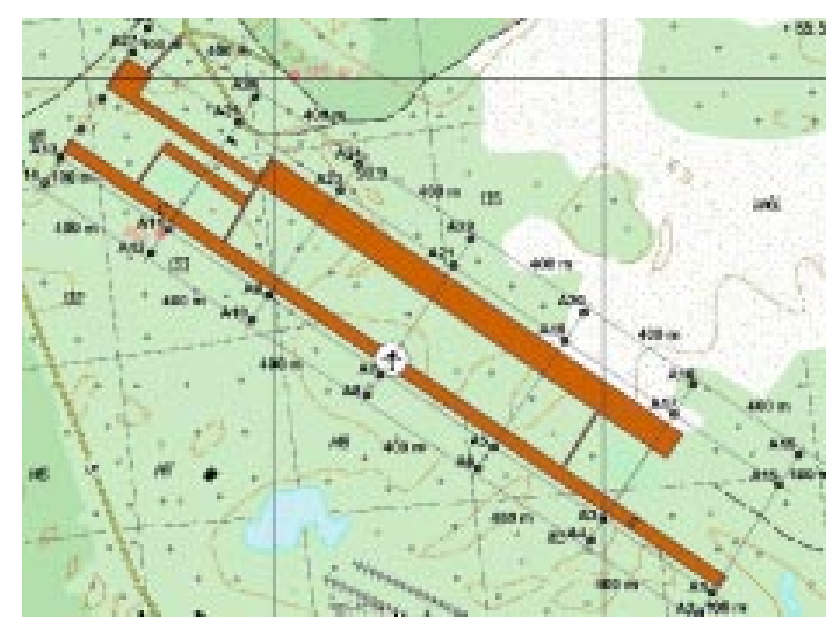

Fig 1. Military airport. Dots mark soil sampling points

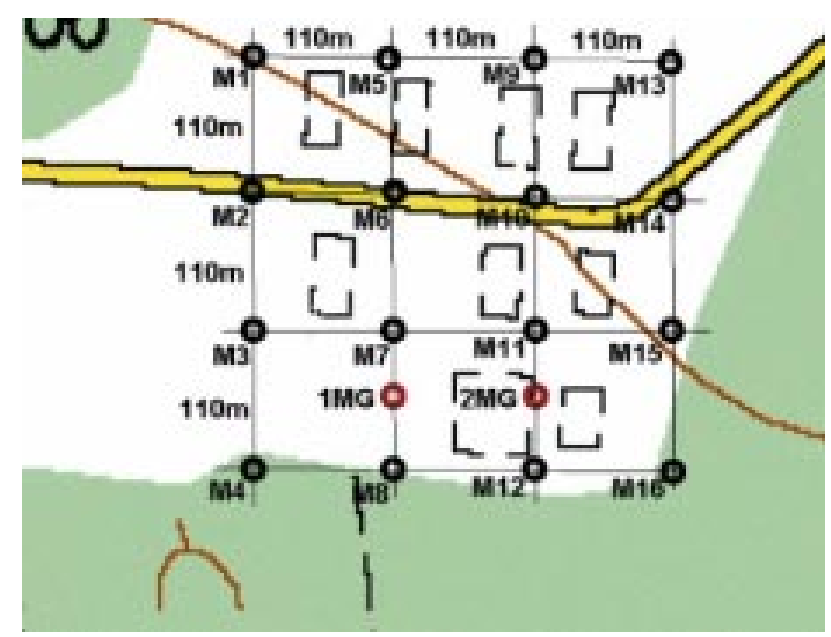

Fig 2. Abandoned settlement in the territory of Gaižiūnai Military Training Ground. Dots mark soil sampling points standard HN 60:2004 defines a maximum allowed concentration of oil products as $50 \mathrm{mg} / \mathrm{kg}$ (for heavy oil products, C6-28), and $30 \mathrm{mg} / \mathrm{kg}$ (for light oil products, C>28). Pollution of the lithosphere is estimated in comparison with the highest allowed pollution levels. The aeration zone soil (the upper porous surface of the Earth's crust at a depth of $0,0-0,5 \mathrm{~m}$ ) is considered to be polluted over an allowed level when the recorded amounts of oil products exceed a maximum allowed concentration.

The soil samples were taken to a laboratory of Vilnius Gediminas Technical University, Environmental Protection Department, for analysis with the device AN-2. To achieve the best results of the analysis and the visual presentation of oil product concentration distribution in the surface soil layer of Gaižiūnai Military Training Ground territory the laboratory analysis results were digitalized and processed graphically and mathematically with the use of Surfer 6 Program.

\section{Analysis of investigation results}

Analysis of 28 samples taken in the territory of the landing airport of Gaižiūnai Military Training Ground revealed that the oil product concentration ranged from 28,3 to $290,7 \mathrm{mg} / \mathrm{kg}$ (Figs 3, 4). An average calculated concen-

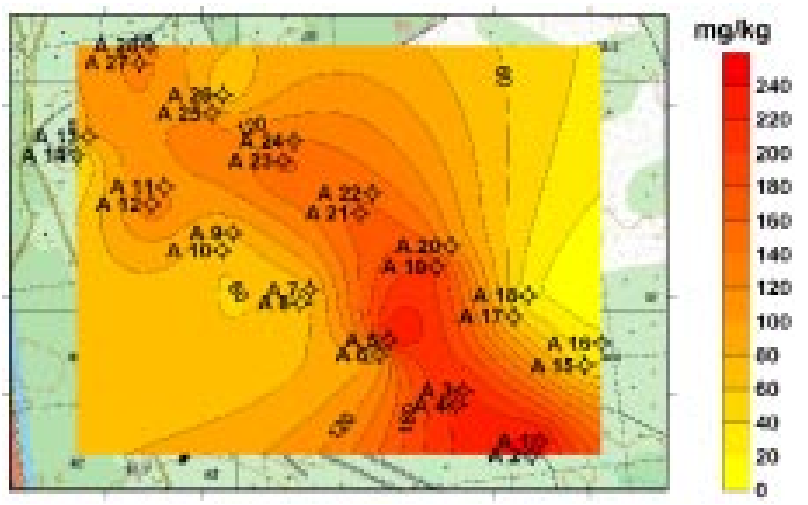

Fig 3. Distribution of oil product concentrations in the military airport soil, $\mathrm{mg} / \mathrm{kg}$

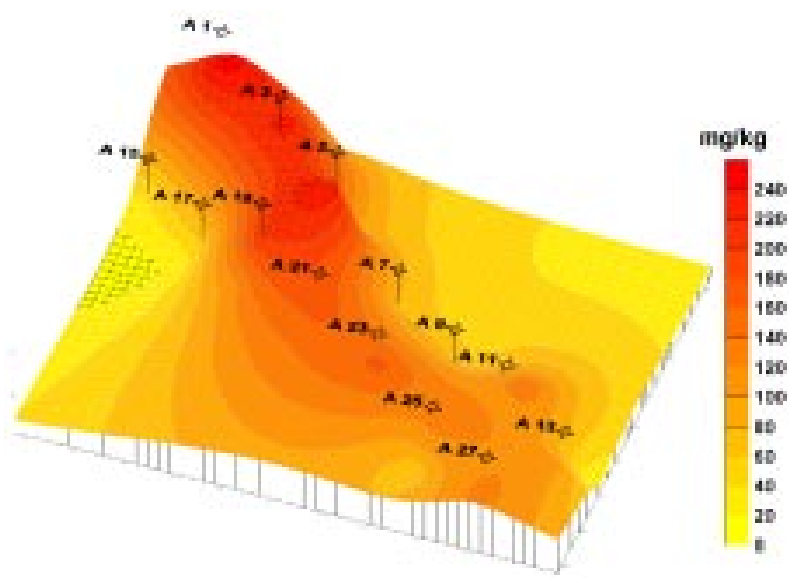

Fig 4. Distribution of oil product concentrations in the military airport. Spatial view 
tration of oil products was $89,69 \mathrm{mg} / \mathrm{kg}$. Such a concentration exceeds almost twice a maximum allowed concentration of oil products defined in the Lithuanian Hygiene Norms (MAC for oil products of $50 \mathrm{mg} / \mathrm{kg}$ ). Oil products are absent from the soil under natural conditions, therefore, their presence in the samples confirm pollution of the soil.

Only 6 samples showed the oil product concentration below a maximum allowed concentration. In the landing airport oil products enter the soil through the leakage of aviation fuel and oils during landing and take-off of planes. Though at present the airport operation is not very intensive, however, the territory of the airport in Gaižiūnai Military Training Ground is considered to be polluted with oil products. As yet treatment of the territory from oil products is not necessary but in future, when both runways are in operation, a constant monitoring of the airport soil pollution with oil products will be unavoidable. The highest concentrations of oil products $(290,7,225,3,225,6$ and $283,2 \mathrm{mg} / \mathrm{kg}$ ), 5-6 times exceeding a maximum allowed concentration, were registered at points A1, A3, A4 and A5 (Figs 3, 4). Such concentrations are unallowably high showing a strong pollution of the investigated area.

Analysis of 6 samples, taken from deeper soil layers (from every $20 \mathrm{~cm}$ to $1 \mathrm{~m}$ in depth) at the first sampling point in the aerodrome territory of Gaižiūnai Military Training Ground, showed bigger than maximum allowed

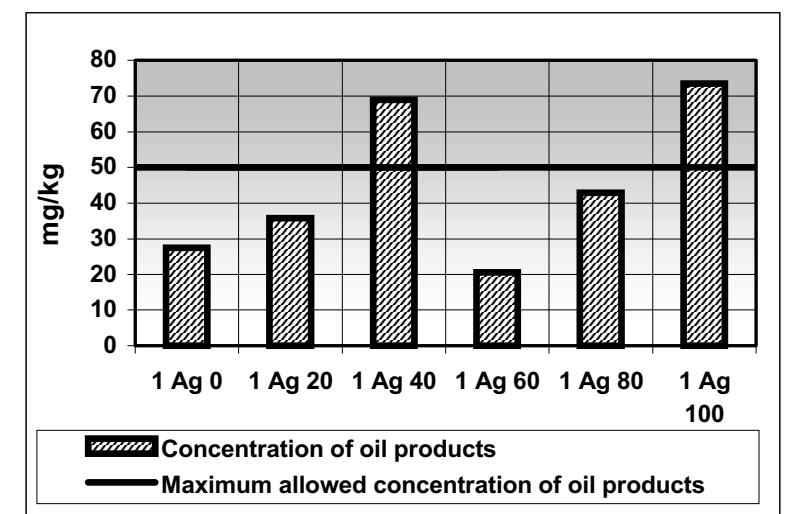

Fig 5. Concentration of oil products at the first soil sampling point in the territory of military airport

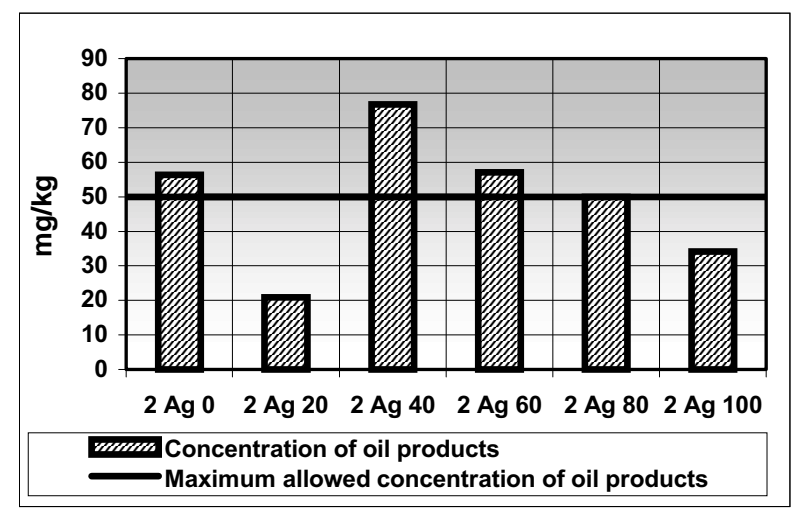

Fig 6. Concentration of oil products at the second soil sampling point in the territory of military airport concentrations in 2 soil samples (Fig 5). Bigger concentrations of oil products were determined in deeper soil layers (the biggest one - at $1 \mathrm{~m}$ depth). At the second soil sampling point only 1 sample with MAC exceeding oil product concentration was found (Fig 6).

As it is seen from Fig 6, it is difficult to find out the tendency of oil product concentration distribution. Anyway, it can be judged, that the concentration of oil products increases with depth.

The results of investigation revealed that oil product concentrations in the soil of the abandoned military settlement varied from 14,3 to $184,5 \mathrm{mg} / \mathrm{kg}$ (Figs 7, 8). A medium determined concentration of oil products was equal to $35,3 \mathrm{mg} / \mathrm{kg}$, i e by $29 \%$ less than a maximum allowed concentration defined in the Lithuanian Hygiene Norms (MAC for oil products of $50 \mathrm{mg} / \mathrm{kg}$ ). Though an allowed level is not exceeded, it is seen that even medium concentrations are quite big in comparison with a natural environment. A maximum concentration of oil products was established at soil sampling point M3 (Figs 7, 8). Such a concentration exceeds three times a maximum allowed concentration. The biggest concentrations of oil products were determined at points M1, M3 and M4. These points match the spots of the abandoned military settlement where some time ago very intensive activities took place because of the presence of a centre for car maintenance and gas-station in the settlement. Such results allow us to conclude

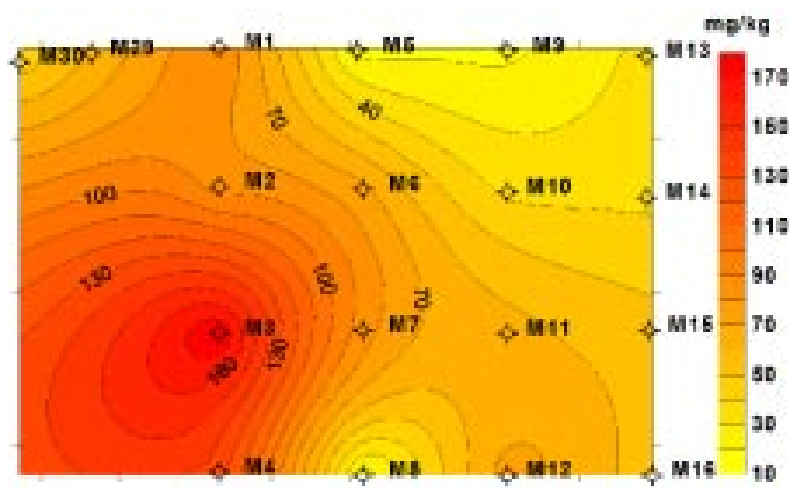

Fig 7. Distribution of oil product concentrations in the soil of abandoned military settlement, $\mathrm{mg} / \mathrm{kg}$

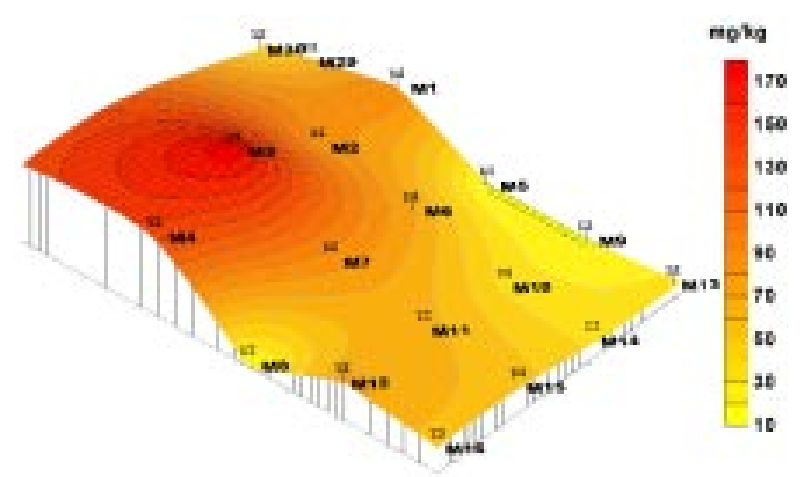

Fig 8. Distribution of oil product concentrations in the soil of abandoned military settlement. Spatial view 
that the territory of the abandoned military settlement in Gaižiūnai Military Training Ground was continually polluted with oil products, as their concentrations in the soil are quite big. Anyway, any activities in this territory are now suspended, though it is not likely that pollution will increase, just the opposite - it will slowly decrease because of natural processes ongoing in the soil.

Analysis of 6 soil samples taken at the first sampling point from deeper soil layers in the territory of the abandoned military settlement in Gaižiūnai Military Training Ground revealed that in all the samples oil product concentrations exceeded maximum allowed concentrations, and in 2 samples the determined concentrations were twice bigger than MAC. The biggest concentrations were determined at a depth of $40 \mathrm{~cm}$ and $1 \mathrm{~m}$, while on the surface they were smaller (Fig 9). The results obtained after analizing the soil samples from the second sampling point revealed that the biggest oil product concentrations were at a depth of $1 \mathrm{~m}$, i e it was 3 times bigger than a maximum allowed concentration. In general, almost all the determined concentrations (except 2 samples) were bigger than MAC, and they were bigger in deeper soil layers

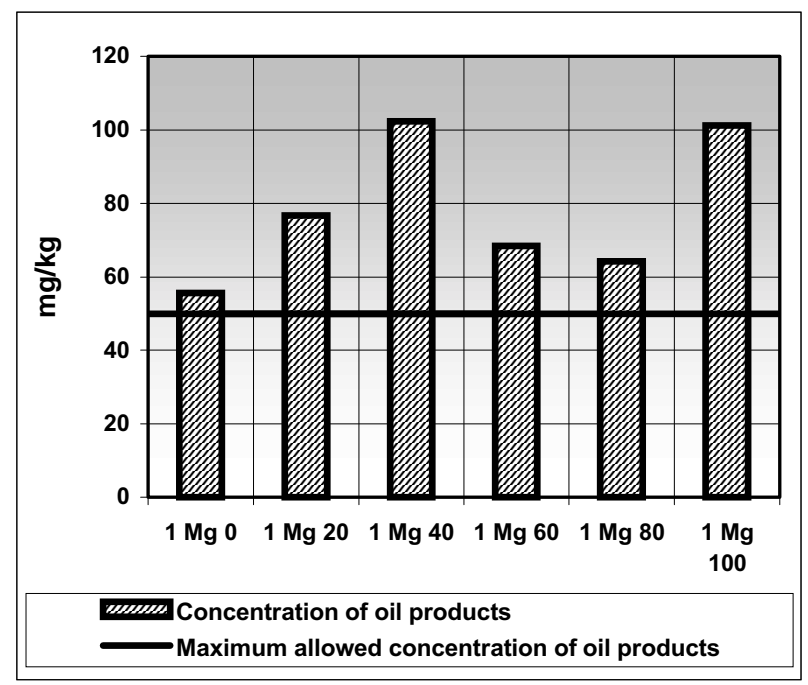

Fig 9. Concentration of oil products at the first soil sampling point in the territory of abandoned military settlement

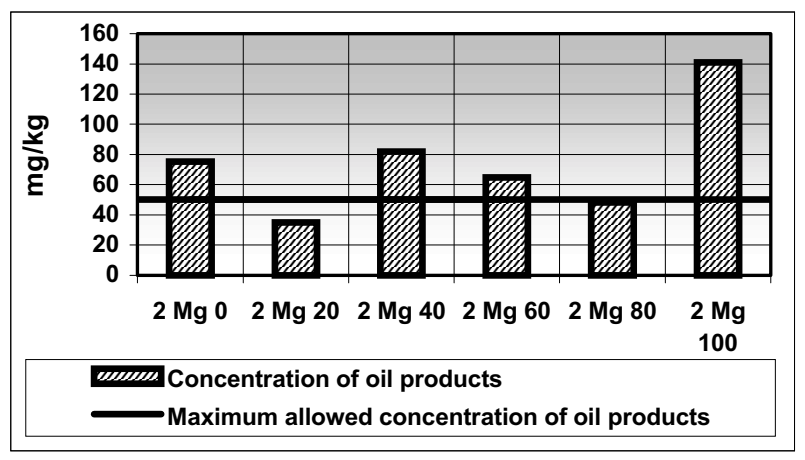

Fig 10. Concentration of oil products at the second soil sampling point in the territory of abandoned military settlement
(Fig 10). Such results show that pollution with oil products has stopped (pollution is not present on the surface), because military activities in this territory do not take place any more.

\section{Mathematical modeling of oil product infiltration into deeper soil layers}

An extensive experimental analysis in the object leads to a conclusion that the level of pollution is not critical. However, a constant monitoring is necessary to observe further migration of some pollutants in the soil. To determine oil product migration into deeper soil layers it is necessary to model the situation. For this purpose critical points (with the highest determined concentrations of oil products) in the military airport territory were selected, and modeling was performed, keeping in mind the determined concentrations of oil products. VS2TDI mathematical modeling program was used to solve this task, since most of its features are suitable for assessing pollutant infiltration into the soil [13-16].

The modeling of pollutant dispersion was based on

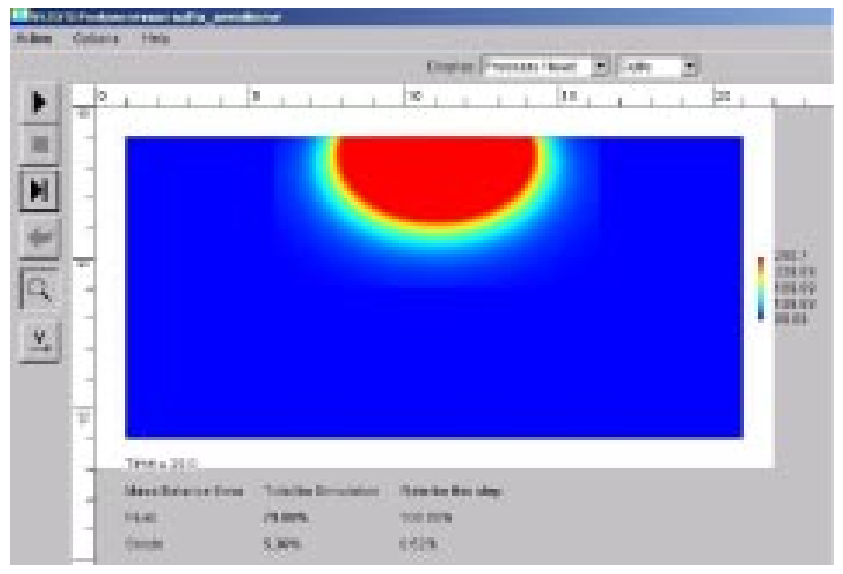

Fig 11. Dispersion of oil products in the soil after 10 years

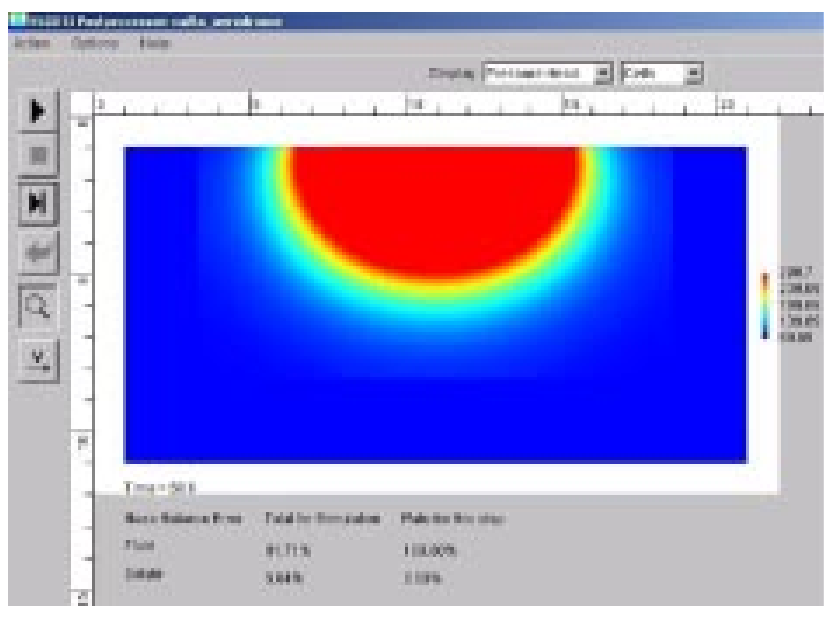

Fig 12. Dispersion of oil products in the soil after 50 years 
the data received from analysis of soil samples taken in the airport territory of Gaižiūnai Military Training Ground. The main task of this modeling was to predict the path and tendency of oil product infiltration into the soil during 50 years.

The simulation was performed in the volume model of $20 \times 10 \mathrm{~m}$ size. Soil used in the model is of various types - average granule sand, sandy soil and fine sand. The layer for average-granule sand is of $2 \mathrm{~m}$, for sandy soil - of $3 \mathrm{~m}$ and for fine sand $-5 \mathrm{~m}$. These are the soil types predominating in the territory of the airport.

The modeled situation relied on the following prepositions: pollutants are spilled on the surface layer of the model soil, and changes are observed during the time interval of 50 years. Pollutants enter the volume of the model only through a $1 \mathrm{~m}$ length segment in the middle of the model surface. The aquifer is set at a 9,5 $\mathrm{m}$ depth from the surface of the model. The pressure of water is $1,0 \mathrm{~m}$.

The determined concentration of oil products at point A1 (Figs 3, 4) in the territory of the military airport was $290,7 \mathrm{mg} / \mathrm{kg}$ (when a maximum allowed concentration is $50 \mathrm{mg} / \mathrm{kg}$ ). The simulation of oil product dispersion in the soil was based on the following time moments: 10 and 50 years. In Figs 11, 12 below the dispersion of a pollutant is presented at different time moments.

Figs 11, 12 reflect not only the depth of oil product migration, but also the influence of the soil type on the migration of oil products. The dispersion of oil products in a sandy soil is more horizontal, while vertical penetration increases when reaching coarse sand. After 1 year oil products reach a depth of $0,3-0,4 \mathrm{~m}$, after 5 years the highest concentration of oil is traced at a depth of $0,8-0,9 \mathrm{~m}$. After 10, 25 and 50 years oil products reach, respectively, a depth of 2, 0, 2, 8 and almost $4 \mathrm{~m}$.

Increase of vertical penetration is noted in coarse sand compared to that in a sandy soil. In a horizontal line within 50 years oil dispersion was $10 \mathrm{~m}$ compared to the initially simulated one of $1 \mathrm{~m}$.

\section{Conclusions}

1. Major pollutants in the old soviet army's military training grounds are as follows: oil products, various chemicals, components of rocket fuel and multifarious waste. Oil products receptacles, transfusion fields, garages and repair shops, gas stations, washing quarters and other places where oil products were used are the main sources of soil and groundwater pollution.

2. The main factors that cause the soil pollution with oil products are very intensive military activities, using different types of transport means and ignorance of environmental safety, when fuel spills are not avoided.

3. For succesful dealing with environmental problems present in military training grounds, first it is necessary to determine pollution levels, and the most critical spots where immediate intervention is needed.

4. The results of investigation performed in Gaižiūnai Military Training Ground revealed territories most polluted with oil products. It was determined that bigger concentrations of oil products were present in the soil in the territory of the aerodrome, than those in the territory of the abandoned military settlement. It is quite logical, as fields directly used for the needs of transport are usually polluted with oil products.

5.Analysis of 28 soil samples taken in the territory of the landing airport showed an average oil product concentration of $89,69 \mathrm{mg} / \mathrm{kg}$. Such a concentration exceeds almost twice a maximum allowed value and shows an unallowable pollution level.

6. A medium determined concentration of oil products in soils of the abandoned military settlement was equal to $35,3 \mathrm{mg} / \mathrm{kg}$, i e by $29 \%$ less than a maximum allowed concentration, and more than twice less than that in the territory of the landing airport. Any activities in this territory are now suspended, so it is not likely that pollution will increase, just the opposite - it will slowly decrease because of natural processes ongoing in the soil.

7. The results of performed modeling revealed that the dispersion of oil products in a sandy soil was more horizontal, while vertical penetration increased, when reaching coarse sand. After 50 years pollutants almost reached a depth of $4 \mathrm{~m}$. Looking at a horizontal line, oil dispersion after 50 years reached $10 \mathrm{~m}$ compared with the simulated one of $1 \mathrm{~m}$.

\section{References}

1. Baltrènas, P.; Ignatavičius, G. Strategy of Military Land Reuse in Lithuania. Approaches to the Implementation of Environment Pollution Prevention Technologies at Military Bases. RTO Proceedings, Vol 39, No 12, NATO Publishing: Cedex (France), 2000, p 1-7.

2. Baltrènas, P.; Oškinis, V.; Ignatavičius, G.; Kumpienè, J. Mechanical disturbance of soils in the field of trainings in the Lithuanian central firing ground in Pabrade and possibilities of environmental protection improving. Environmental Engineering (Aplinkos inžinerija), Vol IX, No 2. Vilnius: Technika, 2001, p 103-109.

3. Renner, M. Assessing the Military's War on the Environment. State of the World: New York-London, 1991, p. 315.

4. Baubinas, R.; Taminskas, J. Natural resources using for military concerns: ecological consequences. In: Geological Survey of Lithuania. Vilnius, 1997-1998. 258 p.

5. Benker, K. W. Removing metals from soil. Civil Engineering, Vol 65, No 10. New York: American Society of Civil Engineers, 1995, p 69-71.

6. Greičiūtè, K.; Vasarevičius, S. Investigation of the Decrease of Soil Organic Matter and Soil Pollution by Heavy Metals in Areas Intensively used for Military Activities. In: Proceedings of the Sixth Symposium and Exhibition „Environmental Contamination in Central and Eastern Europe and the Comonwealth of Independent States", held in Prague, Czech Republic 1-4th of September, 2003, p. 527.

7. Baltrènas, P.; Vasarevičius, S.; Greičiūtè, K.; Vilutienè, V. Influence of military activities on composition and structure of soil. Ecology and Industry of Russia (Экология и промышленность России), 6, Sankt-Petersburg: JSC „Kalvis“, 2003, p 36-40. 
8. Vasarevičius, S.; Greičiūtè, K. Investigation of soil pollution with heavy metals in Lithuanian military training grounds. Journal of Environmental Engineering and Landscape Management, Vol XII, No 4, Vilnius: Technika, 2004, p 132-138.

9. Brady, N. C. The Nature and Properties of Soils $\left(10^{\text {th }}\right.$ Edition). London: MacMillan, 1990. 542 p.

10. Ceburnis, D., Steinnes, E., Kvietkus, K. Estimation of metals uptake efficiencies from precipitation in mosses in Lithuania. Chemosphere, Vol 38, No 2, Elsevier LTD, 1999, p 445-455.

11. Kadunas, V. et al. Geochemical atlas of Lithuania. In: Geological survey of Lithuania. Vilnius, 1999. 162 p.

12. Baltrėnas, P.; Ignatavičius, G.; Vaišis, V. Investigation of soil pollution with heavy metals in Pabrade Central Military Training Ground. Environmental Engineering (Aplinkos inžinerija), Vol IX, No 1. Vilnius: Technika, 2001, p 3-8 (in Lithuanian).
13. Rifai, H. S.; Bedient, P. B.; Wilson, J. T.; Miller, K. M. and Armstrong, J. M. Biodegradation Modelling at Aviation Fuel Spill Site. Journal of Environmental Engineering, Vol 117, No 5, New York: American Society of Civil Engineers, p 1007-1030.

14. Achaz, Rudolf K. Invertebrates in Risk Assessment. Development of a Test Battery and of Short Term Biotests for Ecological Risk Assessment of Soil. Journal of Soils \& Sediments 2 (4), 2002, p 174-178.

15. Baltrènas, P.; Paliulis, D.; Vaišis, V. Oil product biosorbent SPHAG-sorb. Environmental Engineering (Aplinkos inžinerija), Vol X, No 3. Vilnius: Technika, 2002, p 103107 (In Lithuanian).

16. Pierznski, G. M.; Sims, J. T. and Vance, G. F. Soils and Environmental Quality. Lewis, Boca Raton, FL, 1993. $313 \mathrm{p}$.

\title{
DIRVOS UŽTERŠTUMO NAFTOS PRODUKTAIS INTENSYVIAUSIAI NAUDOJAMOSE GAIŽIŪNŲ KARINIO POLIGONO TERITORIJOSE TYRIMAI IR IVERTINIMAS
}

\author{
S. Vasarevičius, K. Greičiūtė, E. Šiaulytė \\ S a n tra k a
}

Pastaruoju metu Lietuvoje ypač aktuali aplinkos taršos problema. Daug dėmesio skiriama teršalu šalinimui iš teritorijų, kuriose ir praeityje, ir pastaruoju metu vyksta aktyvi karinè veikla. Buvusiose îvairios paskirties karinèse bazėse ir specialios paskirties karinėse teritorijose aptinkama organinėmis medžiagomis (nafta ir jos produktais) labai užterštų dirvožemio plotų. Paviršinis dirvožemis yra viena iš pirmuju gamtinių sistemų, tiesiogiai veikiama bet kokio lygio taršos, jame kaupiasi teršalai. Vanduo, skverbdamasis pro naftos angliavandenilių isotintą gruntą, ištirpina ir išplauna jame esančias medžiagas ir pats užsiteršia ivairiais naftos produktais bei sunkiaisiais metalais.

Šiame darbe - pasirinktame veikiančiame Ruklos - Gaižiūnu poligone aplinkos užterštumas tirtas kaip karinès veiklos padarinys. Remiantis atliktų dirvožemio užterštumo naftos produktais tyrimų rezultatais detaliai išanalizuota esama dirvožemio būkle ir nustatytos labiausiai pažeistos vietos.

Raktažodžiai: kariniai poligonai, dirvožemio tarša, naftos produktai, matematinis modeliavimas.

Saulius VASAREVIČIUS. Dr, Assoc Prof (since 2003), Dept of Environmental Protection, Vilnius Gediminas Technical University (VGTU).

Doctor of Science (air-cleaning devices), VTU (now VGTU), 1995. Master of Science, VTU, 1991. First degree in Civil Engineering and Management, Vilnius Civil Engineering Institute (VISI, now VGTU), 1989. Probation in Germany. Research interests: environmental management, air pollution.

Kristina GREIČIŪTĖ. Master, doctoral student, Dept of Environmental Protection, Vilnius Gediminas Technical University (VGTU).

Master of Science (environmental protection engineering) (2002), Bachelor of Science (environmental engineering) (2002), VGTU. Publications: co-author of 12 research papers. Research interests: negative impact of military activities on the soil, soil pollution with heavy metals, remediation technologies.

Edita ŠIAULYTE். Master, Dept of Environmental Protection, Vilnius Gediminas Technical University (VGTU).

Master of Science (environmental protection engineering) (2005), Bachelor of Science (environmental engineering) (2002), VGTU. 